\title{
Presence of orange rust on sugarcane in the state of Pernambuco, Brazil
}

\author{
Andréa Chaves ${ }^{1}$, Djalma Euzébio Simões Netoํㅜ, João de Andrade Dutra Filho ${ }^{1}$, Alexandre Campelo de \\ Oliveira $^{1}$, Walber Douglas de Lima Rodrigues ${ }^{1}$, Elvira Maria Régis Pedrosa ${ }^{2}$, Viviane Jurema Lopes \\ Borges $^{3}$ \& Paulo Roberto Pereira de França ${ }^{4}$
}

'Estação Experimental de Cana-de-Açúcar do Carpina, Universidade Federal Rural de Pernambuco, 55810-000, Carpina, PE, Brazil; ${ }^{2}$ Departamento de Agronomia, Universidade Federal Rural de Pernambuco, 52171-900, Recife, PE, Brazil; ${ }^{3}$ Ministério da Agricultura e Abastecimento, 50761-000, Recife, PE, Brazil; ${ }^{4}$ Agência de Defesa e Fiscalização de Pernambuco, 50711000, Recife, PE, Brazil

Author for correspondence: Andréa Chaves, e-mail: achavesfiuza@yahoo.com.br

\begin{abstract}
Sugarcane leaf rust symptoms were observed on seven month-old plants in March 2012 at Santa Teresa Farm, north coast of Pernambuco, Brazil. Plants were identified as a genotype coded as RBUFRPE0032 developed by the Sugarcane Breeding Program of Universidade Federal Rural de Pernambuco (UFRPE/EECAC). Evaluations under field conditions showed characteristic leaf rust symptoms and high severity. Analysis of symptomatic leaves under the optical microscope at the Plant Pathology Laboratory of UFRPE/EECAC confirmed the presence of fungal urediniospores showing specific characteristics of the fungus. Molecular evaluation by real-time PCR yielded positive results for Puccinia kuenhii. This is the first report of sugarcane leaf rust in Pernambuco. Although the disease has been reported in other Brazilian states, producers and researchers are worried since the behavior of promising commercial varieties and clones from breeding programs directed at the soil and climatic conditions of the state is unknown. The Ministry of Agriculture in Pernambuco was officially informed for notification purposes.
\end{abstract}

Key words: Puccinia kuenhii, Saccharum, epidemiology, plant protection

The worldwide concern for the adoption of clean energy techniques has caused an expansion of sugarcane growing areas for ethanol production in Brazil, contributing to the country's leadership in the world ranking of sugarcane producers with more than 9 million hectares cultivated with the crop (IBGE, 2012). Because of Brazil's continental dimensions, investigators routinely screen sugarcane genotypes for greater adaptability and stability under specific regional conditions, rather than to more general features such as pest and disease resistance.

Historically, orange rust caused by Puccinia kuenhii E. J. Butler has occurred in sugarcane producing countries of Asia since the 1890's (Ryan and Egan, 1989). This disease was considered secondary in Australia up to the end of the 1990's, when it became epidemic on the variety Q124 which was then grown over large areas, resulting in high economic losses for the sugar/ethanol industries of that country (Magarey et al., 2001). Subsequently, the disease was reported in Florida (Comstock et al., 2008), Guatemala (Ovalle et al., 2008), Mexico, El Salvador and Panama (Flores et al., 2009), Cuba (Pérez-Vicente et al., 2009), Costa Rica and Nicaragua (Chavarría et al., 2009) and in Colombia (Cadavid et al., 2012), reducing agricultural productivity of susceptible sugarcane genotypes (Zhao et al., 2011).
In Brazil, the disease was initially reported in sugarcane fields of São Paulo and Paraná states (Barbasso et al., 2010) attracting the attention of infestigators worldwide due to its aggressiveness and fast dissemination (Infante et al., 2009). Up to 2010, orange rust had been reported in the states of Minas Gerais, Goiás, Espírito Santo, Mato Grosso do Sul and Rio de Janeiro (Ferrari et al., 2010). In 2012, the disease was reported in Northeastern Brazil in the state of Rio Grande do Norte (Cruz et. al., 2012).

In anticipation of the arrival of orange rust in Brazilian sugarcane fields, the Rede Interuniversitária para o Desenvolvimento do Setor Sucroalcooleiro ("Interuniversity Network for The Sugar/Ethanol Industries", RIDESA), which integrates sugarcane breeding programs of all Federal universities in the country, had been sending commercial varieties and promising genotypes for countries where the disease was taking place, so they could be planted and evaluated for orange rust resistance. With the arrival of orange rust in São Paulo, the behavior of these materials under the soil and climate conditions of northeastern Brazil became especially relevant.

The main concern relates to RB72454, a parental of RB867515 (extensively planted throughout the country) which showed high susceptibility when planted in other countries (Magarey, 2007), although subsequent studies 
demonstrated resistance of RB867515 in areas affected by the disease both within and outside Brazil. The most susceptible varieties reported in Brazilian sugarcane fields, especially in São Paulo and Paraná, are RB72454, SP891115 and SP84-2025 (MAPA, 2010), whereas RB855156 and SP81-3250 are less susceptible and present lower disease severity. According to Hoffmann et al. (2010), 25.3 $\%$ of the sugarcane growing area in Brazil is cultivated with genotypes with a response similar to RB867515.

Since growing susceptible varieties under favorable conditions for disease development should be avoided (Martins, 2010), the increase in use of $P$. kuenhii resistant genotypes may affect genotype resistance due to the pathogen's variability (Magarey et al., 2001). Occurrence of rain associated with high relative humidity and high summer temperatures, as well as frequent shifts in heat and cold temperatures during autumn (Ovalle et al., 2009; Magarey, 2000) are favorable conditions for disease development. Use of resistant varieties, chemical and cultural control (Huang, 2004; Flores, 2009) are the most frequently used techniques for orange rust management. However, genotype response and the plant age are the conditions that mostly affect disease progress in field. In highly susceptible varieties disease breaks out in four to five months (Minchio et al., 2011).

Aware of the economic losses resulting from orange rust spreading to Pernambuco, the sugarcane breeding program of the Universidade Federal Rural de Pernambuco/ Estação Experimental de Cana-de-açúcar do Carpina (PMGCA/UFRPE/EECAC) was alert to P. kuenhii detection in sugarcane fields. In March 2012, when monitoring experimental fields in Santa Teresa Factory - Purgatory Farm, Goiana, Pernambuco ( $07^{\circ} 45^{\prime} 49^{\prime \prime} \mathrm{S}$ and $\left.35^{\circ} 05^{\prime} 35^{\prime \prime} \mathrm{W}\right)$, typical symptoms of orange rust were observed on seven month-old plants of the genotype RBUFRPE0032. This genotype was present in a field of competition varieties, along with sixteen other promising genotypes developed by the breeding program of PMGCA/UFRPE/EECAC. Disease severity evaluation on +3 leaf using a diagrammatic scale (Amorim et al., 1986) characterized susceptibility to the disease. Chlorotic spots in the leaves progressed to exposing spores lesions. Grouped orange rust pustules were ordinarily found in the middle third and bottom of the leaves (Figure 1), a specific characteristic of $P$. kuenhii in sugarcane, also described by Martins (2010) and Glynn et al. (2010). According to Glynn et al. (2010), these symptoms distinguish P. kuenhii from Puccinia melanocephala, reported in Pernambuco since the 1980s and quite common in sugarcane fields in northeastern Brazil.

Symptomatic leaves were collected and taken to the Plant Pathology Laboratory of the Sugarcane Experimental Station. Characterization of fungal structures under the optical microscope showed yellowish to light brown ovoid spores presenting equatorial pores and thicker wall at the apical region, reaching 11.5 micrometers (Figure 2), characteristic features of $P$. kuenhii described by Hsieh \& Fang (1983) and by Cruz et al. (2012) when diagnosing this disease in Rio Grande do Norte state. A detailed official document reporting the event was sent to Superintendence of the Agriculture Department of Pernambuco for notification
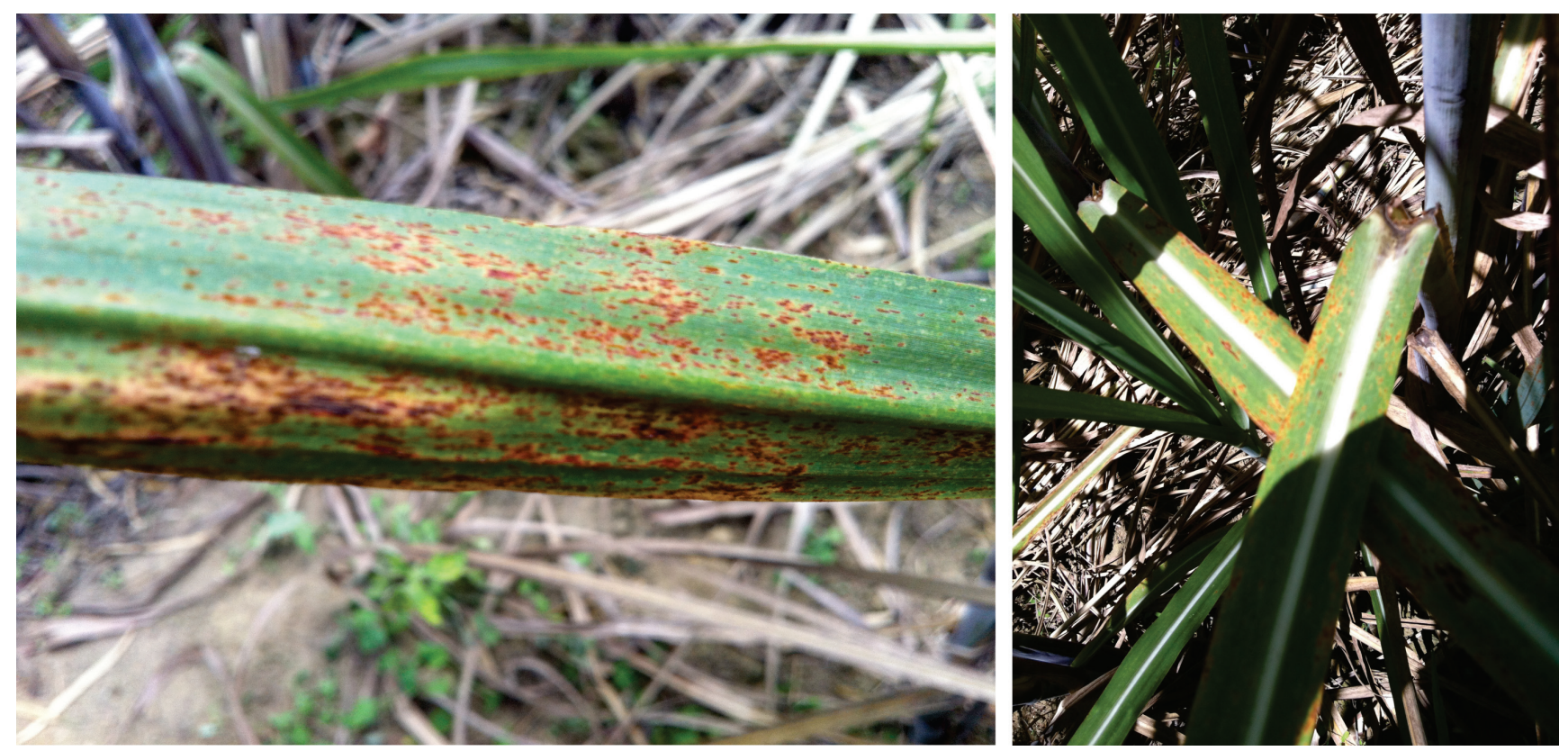

FIGURE 1 - Symptoms of orange rust (Puccinia kuenhii) in sugarcane leaves of the RBUFRPE0032 genotype. Leaf rust pustules present in the middle third and bottom of the leaves, observed in the experimental field in Goiana, PE, March 2012. 

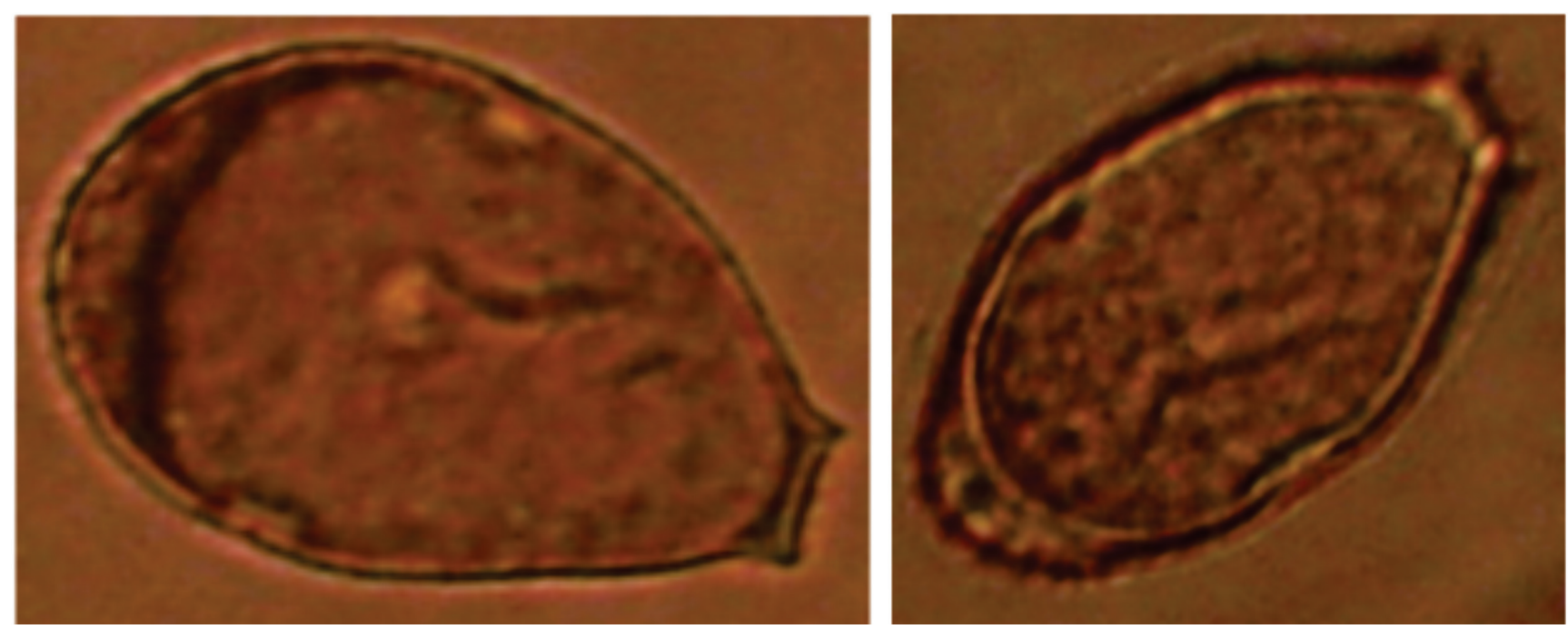

FIGURE 2 - Urediniospores of Puccinia kuenhii collected from leaves of sugarcane plants grown in Goiana, PE, observed in the optical microscope showing equatorial pores and wall thickening in the anterior region.

of orange rust arrival in the state of Pernambuco. Supported by State and Federal agencies, a real-time PCR assay was developed using primers PK2-F/PK2-R and probe PK2-P, from DNA extracted from sugarcane symptomatic leaf samples. Some of the material was sent a commercial diagnostics laboratory for diagnosis of the problem in plants. The Plant Health Diagnostic Laud 10580/2012 originated from those agencies concluded there was $98 \%$ coverage of Puccinia kuenhii sequences, characterizing a positive response for Puccinia kuenhii.

The presence of orange rust in the state of Pernambuco demonstrates that this disease is rapidly spreading in Brazilian sugarcane fields.

\section{REFERENCES}

Amorim L, Bergamin Filho A, Sanguino A, Cardoso CON, Moraes VA, Fernandes CR (1987) Metodologia de avaliação de ferrugem da cana-de-açúcar (Puccinia melanocephala). Boletim Técnico Copersucar 39:13-16.

Barbasso D, Jordão H, Maccheroni W, Boldini J, Bressiani J, Sanguino A (2010) First report of Puccinia kuenhii, causal agent of orange rust of sugarcane, in Brazil. Plant Disease 94:1170.

Cadavid M, Angel JC, Victoria JI (2012) First report of orange rust of sugarcane caused by Puccinia kuenhii in Colombia. Plant Disease 96:143.

Chavarría E, Subirós F, Vega J, Ralda G, Glynn NC, Comstock JC, Castlebury LA (2009) First report of orange rust of sugarcane caused by Puccinia kuenhii in Costa Rica and Nicaragua. Plant Disease 93:425.

Comstock JC, Sood SG, Glynn NC, Shine JM, McKemy JM, Castlebury LA (2008) First report of Puccinia kuenhii, causal agent of orange rust of sugarcane, in the United States and Western Hemisphere. Plant Disease 92:175.
Cruz MM, Monteiro, JHA, Barbosa GVS (2012) Primeiro relato da ferrugem alaranjada da cana-de-açúcar (Puccinia kuenhii) no Nordeste do Brasil. Tropical Plant Pathology 37:169.

Ferrari JT, Harakava R, Domingues RJ, Terçariol IML (2010) Mapeamento da ferrugem alaranjada da cana-de-açúcar no Brasil. O Biológico 72:103-170.

Flores RC, Loyo JR, Ojeda RA, Rangel OCA (2009) First report of orange rust of sugarcane caused by Puccinia kuenhii in Mexico, El Salvador, and Panama. Plant Disease 93:1347.

Glynn NC, Dixon LJ, Castlebury LA, Szabo LJ, Comstock JC (2010) PCR assays for the sugarcane rust pathogens Puccinia kuenhii and Puccinia melanocephala and detection of a SNP associated with geographical distribuition in Puccinia kuenhii. Plant Pathology 59:703-711

Hoffmann HP, Chapola RG (2010) Estimativa de perdas com a ferrugem alaranjada. Available at: pmgca.dbv.cca.ufscar.br/ dow/Apresentacao $\%$ E7\%E30\%20Ferrugem $\% 20$ Alaranjada.pdf. Accessed on September 11, 2010.

Hsieh WH, Fang JG (1983) The uredospore production of Puccinia melanocephala and Puccinia kuenhii in sugarcanes. Plant Protection Bulletin 25:239-244

Huang S (2004) Progress of sugarcane disease research in China: Recent developments. Sugarcane Agriculture 6:261-265.

IBGE (2012) SIDRA: Sistema IBGE de Recuperação Automática. Available at: www.sidra.ibge.gov.br. Accessed on April 27, 2012.

Infante D, Martinez B, Gonzalez E, Gonzalez N (2009) Puccinia kuenhii (Kruger) Butler y Puccinia melanocephala H. Sydow y P. Sydow. en el cultivo de la caña de azúcar. Revista Protección Vegetal 24:22-28

Magarey RC (2000) Orange rust. In: Root P, Bailey RA, Saumtally AS (Eds.) A Guide to Sugarcane Diseases. Montpelier France. CIRAD ISSCT. pp. 121-125.

Magarey RC, Willcox T, Croft B, Cordingley A (2001) Orange rust, a major pathogen affecting crops of Q124 in Queensland 
in 2000. Proceedings of the Australian Society of Sugar Cane Technology 23:274-280.

Magarey RC (2007) Estimating disease-associated yield losses in breeding selection trials - Endemic diseases: Pachymetra root rot, orange rust and yellow spot. BSES Internal Report PR07004.

Martins TD (2010) Aspectos epidemiológicos da ferrugem alaranjada da cana-de-açúcar. DS Thesis, ESALQ-USP. Piracicaba SP, Brazil.

MAPA (2010) A ferrugem alaranjada (Puccinia kuenhii). Available at: www.agricultura.gov.br/pls/portal/docs/page/mapa/principal/ destaque. Accessed on April 28, 2012.

Minchio CA, Canteri MG, Rocha JA (2011) Germinação de uredosporos de Puccinia kuenhii submetidos a diferentes temperaturas e tempos de incubação. Summa Phytopathologica $37: 211-214$
Ovalle W, Comstock JC, Glyn NC, Castlebury LA (2008) First report of Puccinia kuenhii, causal agent of orange rust of sugarcane, in Guatemala. Plant Disease 92:973.

Ovalle W, Orozco H, Quemé J, Melgar M, Garcia S (2010) La roya naranja en Guatemala y estrategias para su manejo. Available at: www.sugarjournal.com/articles/active_subs/2009/August2009. Accessed on May 062012.

Pérez-Vicente L, Martín-Triana EL, Barroso F, Martínez-de la Parte E, Borrás-Hidalgo O, Hernández-Estévez I (2009) Definitive identification of orange rust of sugarcane caused by Puccinia kuenhii in Cuba. New Disease Reports 20:16.

Purdy LH, Dean JL (1983) Rust, an old disease with new importance in sugarcane. Sugar y Azúcar 78:30-32.

Zhao D, Glynn NC, Glaz B, Comstock JC, Sood S (2011) Orange rust effects on leaf photosynthesis and related characters of sugarcane. Plant Disease 95:640-647. 